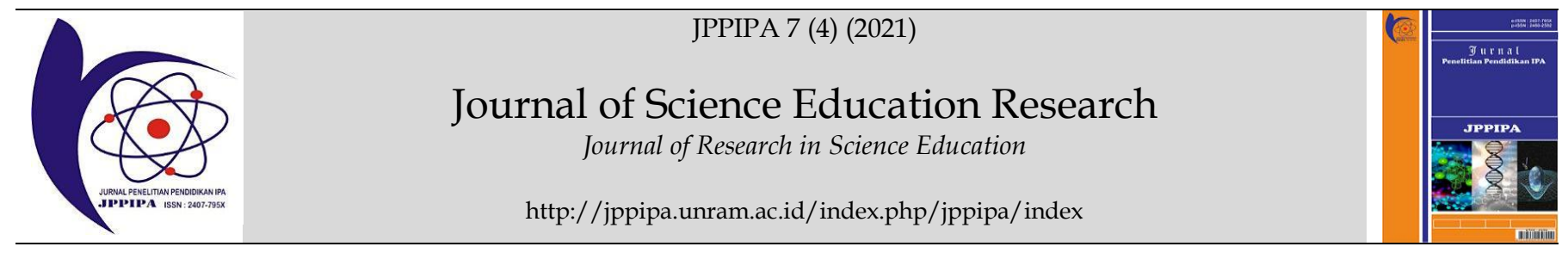

\title{
The Effect of Biology Online Learning Based on Edmodo Group WhatsApp on Learning Outcomes Based on the Learning Motivation of Students
}

\author{
Eldyana Rahayu Putri1 ${ }^{*}$, Moralita Chatri1 ${ }^{1}$, Syamsurizal1, Irdawati ${ }^{1}$ \\ ${ }^{1}$ Department of Biology, Prodi PPs Biology Education, Padang State University, Padang, Indonesia.
}

DOI: $10.29303 /$ ippipa.v7i4.775

\section{Article Info}

Received: June 2nd, 2021

Revised : September 19th, 2021

Accepted: October 1st, 2021

\begin{abstract}
COVID-19 pandemic has changed the order of people's lives, including the education sector. The transition from conventional learning to online learning often encounters obstacles, including determining the appropriate type of online learning media. One solution that can be used is to use learning media in the form of WhatsApp assisted by Edmodo in online learning. This study aims to determine the effect of using online learning media in the form of WhatsApp assisted by Edmodo in improving learning outcomes in terms of students' learning motivation. The experimental technique used was a $2 \times 2$ factorial design. The study population was all students of class X SMA Negeri 1 Bukittinggi. Sampling was done by using the purposive proportional sampling technique. The learning outcome instrument is a written test, and the learning motivation instrument is a questionnaire, the data analysis technique used two-way ANOVA test and Bonferroni advanced test. The results showed that the average value of learning outcomes in the control class was 79.38 lower than the experimental class, with an average value of 83.50 . Significant differences were also obtained in the group of students with high learning motivation, with an average of 94.00 in experimental and 86.00 in the control classes. Different results were obtained in the group of students with low learning motivation, which had an average of 73.00 in the experimental class and 72.75 in the control class. The learning outcomes obtained are influenced by the interaction of choosing the type of media online learning with students' learning motivation.
\end{abstract}

Keywords: WhatsApp; Edmodo; online learning; learning outcomes; learning motivation.

\begin{abstract}
Citation: $\quad$ Putri, E., Chatri, M., Syamsurizal, S., \& Irdawati, I. (2021). The Effect of Biology Online Learning Based on Edmodo Group WhatsApp on Learning Outcomes Based on the Learning Motivation of Students. Jurnal Penelitian Pendidikan IPA, 7(4), 556-561. doi:https://doi.org/10.29303/ippipa.v7i4.775
\end{abstract}

\section{Introduction}

Online learning is common in the world of education, especially in the 21st century. 21st-century learning is learning that requires students and teachers to be able to take advantage of the power of technology to support the learning process. Even so, teachers rarely use online learning and have focused more on conventional learning so far. The most important reason is the unpreparedness of school facilities and infrastructure to support the realization of effective online learning. However, the COVID-19 pandemic has become a turning point for the progress of the learning process carried out online, especially in Indonesia. It has been more than a year that the implementation of online learning has been used as a solution so that learning can continue even though a pandemic blocks it.

Online learning is emerging as an alternative for educators and students because it does not require them to be face-to-face in the classroom. For students, online learning can encourage learning independence, while for educators, it can increase work professionalism by

\footnotetext{
*Email: eldyanarp@gmail.com
} 
varying the types of learning media and the use of technology in the learning process (Zhafira et al., 2020). The use of information technology in online learning is expected to overcome the limitations of interaction between teachers and students during the online learning process.

The transition from conventional learning processes to online learning often encounters difficulties and obstacles. According to Harjanto \& Dimas (2018), the online learning process transforms traditional knowledge into digital form. The existence of this transformation allows the emergence of sharing opportunities and challenges in its implementation. The challenges of online learning, in general, include system constraints, internet access speed, and internet network coverage. However, the challenges and barriers to online learning faced may differ from school to school. For this reason, schools need to identify the obstacles and obstacles to the online learning process they are facing.

The obstacle faced by the biology teacher of SMA Negeri 1 Bukittinggi in the online learning process is determining the type of learning media that is in accordance with the characteristics of students. Online learning using social media in the form of WhatsApp has several shortcomings, especially in providing assessments and evaluating student performance. In addition, based on the results of student interviews, as many as $89.6 \%$ of students stated that they were not interested in the online learning process being carried out. Less interesting online learning also has an impact on the learning motivation of students. Students are often not actively involved in the online learning process that is being carried out. Rosmayanti and Hilva (2018) \& Ilyas and Annisa (2018) revealed that high and low learning motivation is closely related to the learning outcomes obtained. The higher the level of learning motivation that students have, the higher the learning outcomes obtained, conversely the lower the level of learning motivation, the lower the learning outcomes obtained.

Teachers can make efforts to overcome this problem by combining the types of online learning media used to make them more varied. Based on Jumaeroh and Zuhaida (2019) research, one of the platforms that have been researched and can increase motivation and learning outcomes is Edmodo. The use of learning media in the form of WhatsApp assisted by Edmodo can be one solution that can be utilized. Edmodo is a social network that has features to support learning. Like other social networks, Edmodo accounts can be obtained free of charge by accessing www.edmodo.com. It's just that Edmodo is designed for knowledge and school-based use. This can be seen clearly on the Edmodo start page display. It will be seen that the user login is differentiated whether the user is a teacher, student, or parent of students. Some of the features contained in the online learning system to support e-learning, such as assignments, quizzes, and assessments, are also available in Edmodo.

\section{Method}

This research is an experimental study with a $2 \times 2$ factorial design. The study population was class $X$ students who were registered in the 2020/2021 school year at SMA Negeri 1 Bukittinggi. The sampling technique was carried out by purposive proportional sampling to obtain a sample of class X MIPA 3 and X MIPA 1. Collecting data on learning outcomes was using written tests and measuring learning motivation using validated questionnaires. The written test is in the form of post-test post-test questions that have been validated by experts and empirically with the reliability of the test 0.81 with a very high category. The data analysis technique used two-way ANOVA test and Bonferroni advanced test with the prerequisite for normality and homogeneity tests.

\section{Result and Discussion}

Aprerequisite for conducting the two-way ANOVA test is that the data must be normally distributed and also homogeneous. For that, it is necessary to test for normality and homogeneity first. Following are the results of the normality and homogeneity test of data on differences in student learning outcomes.

Table 1. Results of Normality and Homogeneity Test Results of Student Learning Outcomes

\begin{tabular}{lllll}
\hline No & Parameter & Df & Sign Value. & Description \\
\hline 1 & Normality & 80 & 0.092 & Normal \\
2 & Homogenity & 80 & 0.072 & Homogeneous \\
\hline
\end{tabular}

Normality test used to examine the distribution of data using the SPSS program. Based on Table 1, it can be seen that the data is normally distributed. Besides the normality, the homogeneity of data was also examined with Levane's Test on SPSS programs, and the result showed that data was homogeneous. Based on the normality and homogeneity of data, the two-way ANOVA test prerequisites are met and can be done. Furthermore, the analysis was carried out to see the mean difference between the two treatment groups. The results of the difference in the average learning outcomes obtained can be seen in Table 2 . 
Table 2. The difference in Average Learning Outcomes Based on Learning Motivation

\begin{tabular}{lllll}
\hline No & Classroom & Average & $\begin{array}{l}\text { Learning } \\
\text { Motivati } \\
\text { on }\end{array}$ & Average \\
\hline 1 & Control (WhatsApp) & 79.38 & High & 86.00 \\
& & & Low & 72.75 \\
2 & Experiment & 83.50 & High & 94.00 \\
& (+whatsappedmodo) & & Low & 73.00 \\
\hline
\end{tabular}

In Table 2, it can be seen that there is a difference in the average value of learning outcomes in online learning using WhatsApp compared to learning using WhatsApp assisted by Edmodo. Using WhatsApp, online biology learning obtained lower average scores than students' scores in online learning using Edmodoassisted WhatsApp. In addition, the difference in the average value obtained is also found in groups of students with high and low learning motivation. Students with high motivation tend to have a higher average score than students with low motivation. The hypothesis test (t-test) needs to be done to determine the importance of differences in intermediate learning outcomes obtained by students. The t-test results are spelled out in Table 3.

Table 3. Hypothesis Test Results Difference in Mean Learning Outcomes of Students

\begin{tabular}{llll}
\hline Df & T & Significance & Information \\
\hline 79 & 61.287 & 0.000 & Significant \\
\hline
\end{tabular}

The significance value of the t-test shows the number 0.000 . This value is smaller than the significance level of 0.05 , which means that $\mathrm{H}_{1}$ is accepted. The difference in the average value of student learning outcomes in the two essential competencies is significant or significantly different. Furthermore, a two-way ANOVA test was carried out to see the factors that influenced the difference in the average value of student learning outcomes. In the experimental class, learning using Edmodo and WhatsApp shows the intermediate learning outcomes of students with a high score of 83.50. Sefriani et al., (2021) and Safdari (2021) revealed that the use of Edmodo is beneficial in improving student learning outcomes. In line with the opinion of Mamonto et al. (2021), which states that the use of online learning media in the form of WhatsApp assisted by Edmodo can significantly improve student learning outcomes. This is because the application of online learning using WhatsApp media assisted by Edmodo is more varied and communicative than using only WhatsApp. Halil (2020) adds that students are interested in using elearning media with Edmodo because it looks simple, communicative, and easy to understand. In addition, Edmodo as a learning medium specialized as an online learning platform can complement the shortcomings of
WhatsApp, which is basically only intended as social media.

Kartal's research (2019) reveals that WhatsApp can be used to encourage autonomous learning, enable teachers to become facilitators in learning and develop learning communities. The effect of WhatsApp on student motivation and independence is essential because post-method pedagogy requires autonomous, active, and collaborative language teachers and students, but in the same study, it is revealed that learning with WhatsApp does not provide challenges for students in learning, because basically, the WhatsApp application is not e-learning. Cetinkaya (2017) also states that learning using WhatsApp can improve student learning outcomes compared to conventional learning. However, the problem with sending information messages via the WhatsApp application is the timing of the announcement. Although in limited numbers, some of the statements of students, especially about messages that were not timely that could cause distraction, suggest that special attention should be paid to the timing of messages.

Researchers also encountered this problem in the online learning process that was carried out. The messages sent by the teacher often overlap with the messages of students and between students, so this results in important information that all students may not read. Suppose learning is one-way or only relies on teachers as information providers. In that case, the WhatsApp service can be changed to the WhatsApp business so that only teachers can provide information in the group. However, this cannot be done if the learning is collaborative and expects students' feedback. For that, students must control themselves in sending unnecessary messages to convey critical information properly.

Learning outcomes are closely related to learning motivation possessed by students. Several factors influence students' motivation to learn. Students can increase learning motivation when they are in a constructive classroom learning environment by encouraging discussion. The formation of a cooperative learning environment and small group work can strengthen the level of student motivation to be involved in the learning process. Azmi and Ashari (2017) revealed that the use of Edmodo plays a major role in increasing students' motivation and learning capabilities through video quiz learning and communication with educators and other students.

The implementation of online learning conducted at SMA Negeri 1 Bukittinggi has not found a suitable and effective pattern for use by students. Online learning using WhatsApp is able to increase students' learning motivation during the pandemic and postpandemic Covid-19 (Susilawati and Supriyatno, 2020). WhatsApp Messenger platform for learning takes place optimally because teachers and students can 
communicate and share power point files, Microsoft Word files, JPG files, voice notes, videos, and other resource links (Susilawati and Supriyatno, 2020). However, WhatsApp, which is not fully an e-learning platform, has several shortcomings, especially related to students' assessment or evaluation process. However, WhatsApp as a single learning medium for learning that is fully implemented online is still deemed ineffective in increasing students' motivation to learn. Learning with WhatsApp media can support collaborative learning but lacks students' independent learning because of the unavailability of features such as quizzes that encourage the repetition of independent learning. The use of WhatsApp assisted by Edmodo simultaneously is a choice that teachers can use to support the online learning process.

Adlani and Hanifah research (2020) shows that social media in the form of WhatsApp can be used as an alternative learning media during the Covid-19 pandemic. WhatsApp as a learning medium can be used as a communication tool between students and teachers in remote conditions. On the other hand, Vania et al., (2018) shows that another online learning media, Edmodo, also improves student learning outcomes and motivation. This is because Edmodo facilitates the independent learning process that students can do anytime and anywhere. Faisal (2019) expressed that Edmodo can improve student learning outcomes because Edmodo supports a collaborative learning process that ensures interaction between students to achieve learning goals. In addition, evaluation or assessment of students is easier for the teacher to do. Other research from Charoenwet \& Christensen (2016) also shows that Edmodo can significantly help students be active in practical and theoretical class discussions (applied or analysis) and increase collaboration between learners in the learning process. This is because, through Edmodo, students can get a lot of competencies through the available features.

Motivation to learn is a factor that has a strong correlation with learning outcomes. Rosmayanti (2018) and Ilyas (2018) revealed a significant relationship between motivation and learning outcomes. The higher the learning motivation you have, the better the learning outcomes obtained. Conversely, the lower the motivation to learn, the fewer learning outcomes students get. In addition, the high and low learning motivation of students is also influenced by several factors. These factors include the selection of the type of learning media used. The learning media used in this study is a type of online learning media that can improve student learning outcomes. The selection of online learning media has to go through various considerations. One of them is the students' perceptions of the online learning media used.

Edmodo is one of the most exciting online learning media for students. There are several factors to seeing online learning media appeal to students, especially during the Covid-19 pandemic. The factor is the emergence of learning media that are simple and easy to use, do not use many internet quotas, stimulate enthusiasm and liveliness of students in learning, support the process of distance learning, and allow communication between teachers and students and with other students (Sakkir, 2020).

Table 4. Results of Two-Way ANOVA Test

\begin{tabular}{llllll}
\hline Variable & Mean & df & F & Sign & Inquiries \\
\hline Media & 340.313 & 1 & 7294 & 0.015 & Significant \\
Motivation & 5695.312 & 1 & 108516 & 0.000 & Significant \\
Media * & 300.313 & 1 & 5.008 & 0.022 & $\begin{array}{l}\text { There is } \\
\text { Motivation }\end{array}$ \\
\hline
\end{tabular}

Based on Table 4, the significance of the influence of media value is equal to $0.015<0.05$, which means that the type of online learning media used has a significant effect on student learning outcomes. Likewise, the significance value of learning motivation, which shows the number $0.000<0.05$, means that students' learning motivation significantly affects student learning outcomes. As for the interaction between media and motivation, it can be seen in the media* motivation table column, which shows a significance value of $0.022<0.05$, means that there is an interaction between the type of online learning media used and the motivation to learn in influencing students' learning outcomes (H1 Accepted). The interaction between types of online learning media and learning motivation in influencing differences in the average score of students is illustrated by the following graph.

Estimated Marginal Means of hasil_belajar_KD1

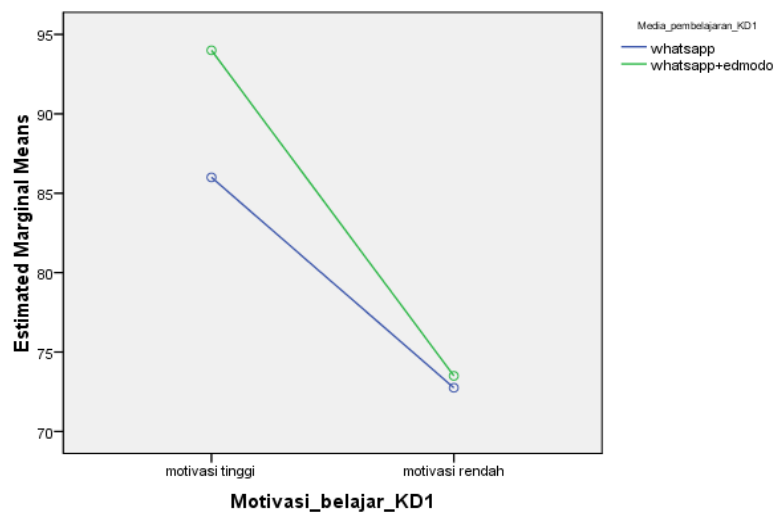

Figure 1. Graph Interaction Media Learning with Learning Motivation

The blue line on the graph shows the learning outcomes of students taught with online learning media such as WhatsApp, while the green line menu shows the learning outcomes of students who are taught using online learning media in the form of whatsapp assisted by Edmodo. 
After knowing the effects of this type of online learning media and learning motivation on the learning outcomes, students in each basic competency need to conduct further tests. It aims to determine which groups have significant interaction between the types of online learning media and learning motivation in influencing differences in average learning outcomes in both sample classes. The follow-up test used was Bonferonni test results Bonferonni can be seen in Table 5 below.

Table 5. The results of the Test of Bonferonni Student Learning Outcomes Learning

\begin{tabular}{lllll}
\hline Motivation & $\begin{array}{l}\text { Control } \\
\text { (MT) }\end{array}$ & $\begin{array}{l}\text { Control } \\
\text { (MR) }\end{array}$ & $\begin{array}{l}\text { Experi- } \\
\text { ment (MT) }\end{array}$ & $\begin{array}{l}\text { Experi- } \\
\text { ment (MR) }\end{array}$ \\
\hline Control (MT) & & & & \\
Control (MR) & $13.25^{*}$ & & & \\
Experiment (MT) & $8.00^{*}$ & $21,25 *$ & & \\
Experiment (MR) & 13.00 * & 0.25 & $21.00 *$ & \\
\hline
\end{tabular}

Description:

MT: High Learning Motivation

MR: Low Learning Motivation

The Results of The Advanced Test from Bonferonni contained in Table 5 showed groups with different interactions between media types and learning motivations, which significantly affected differences in the average grade of student learning outcomes. Signs $\left(^{*}\right)$ indicate interactions between groups are significant or significantly different. This means that only interactions between control classes are those taught using online learning media in WhatsApp in groups of students with low learning motivation. Experimental classes taught with WhatsApp online learning media helped Edmodo students with low learning motivation and insignificant grades, which is 0.25 .

The interaction of choosing the use of online learning media in WhatsApp assisted by Edmodo with high learning motivation has a significant effect on better student learning outcomes. The difference in the average value of learning outcomes based on learning motivation between the experimental and control classes can refer to how learning motivation influences student learning outcomes. Choosing the right and appropriate type of online learning media can increase learning motivation so that online learning media in the form of Edmodo-assisted WhatsApp can be used both for students with low learning motivation and those with high learning motivation.

\section{Conclusion}

Based on the results of the research and discussion that has been presented, the following conclusions can be drawn that using WhatsApp assisted by Edmodo as online learning have a significant effect on learning outcomes, especially to students with high learning motivation. This can happen because WhatsApp and Edmodo support that collaborative and independent learning by students. So that students will balance their capacity with a group and as an independent. On the other hand, students with low learning motivation don't affect too much by using these media as online learning because students with low learning motivation tend to choose collaborative learning over independent learning. But overall, the research results show an interaction between the media used and learning motivation in influencing learning outcomes .

\section{Acknowledgment}

The researcher thanks to the supervisor who has guided in making this research article, then the researcher also thanks to the biology subject teacher at the Public High School in the city of Padang, who has permitted to conduct research at school, and the researcher also thanks to Biology Education PPS Study Program, FMIPA UNP which has facilitated this research.

\section{References}

Adlani, N., \& Hanifah, M. (2020). Media Alternatif Whatsapp (WA) Mengatasi Permasalahan Pembelajaran pada Situasi Pendemi Covid 19 di Kelas PGMI Semester IV. At-Thullab: Jurnal Pendidikan Guru Madrasah Ibtidaiyah, 4(2), 93. https://doi.org/10.30736/atl.v4i2.215

[Indonesian]

Azmi, N., \& Ashari, Z. S. M. (2017). Potential of Edmodo an Educational Social Network Sites (ESNS) in Biology Classroom. International Journal of Academic Research in Business and Social Sciences, 7(11), 1473-1488. https://doi.org/10.6007/ijarbss/v7-i11/3585

Cetinkaya, L. (2017). The impact of WhatsApp uses on success in the education process. International Review of Research in Open and Distance Learning, 18(7), $59-74$. https://doi.org/10.19173/irrodl.v18i7.3279

Charoenwet, S., \& Christensen, A. (2016). The effect of Edmodo learning network on students' perception, self-regulated learning behaviors and learning performance. IMSCI 2016 - 10th International Multi-Conference on Society, Cybernetics and Informatics, Proceedings, Imsci, 297-300.

Faisal, I. A. (2019). The use of Edmodo: Its impact on learning and students' attitudes toward it. Journal of Information Technology Education: Research, 18, 
319-330. Retrieved from: http://search.ebscohost.com/... =ehost-live

Halil, N. I. (2020). The Effectiveness of Using Edmodo as an Online Learning Platform in Covid-19. Jurnal Penelitian dan Pengkajian Ilmu Pendidikan ESaintika, (4) 3, 284-298. https://doi.org/10.36312/e-saintika.v4i3.316

Harjanto, T., \& Dimas S.E.W.S. (2018). Tantangan Dan Peluang Pembelajaran Dalam Jaringastudi Kasus Implementas Elok (E-Learning: Open For Knowledge Sharing) Pada Mahasiswa Profesi Ners. Journal Technology and Teacher Education, 7 (3), 217-226.

http://dx.doi.org/10.35842/jkry.v5i0.282

[Indonesian]

Ilyas \& Annisa, M.L. (2018). Relation of Achievement Motivation and Learning Motivation with Learning Outcomes of Physics Students in Universitas Flores, Kasuari Physics Education Journal, 11 (1), 52-57. https://doi.org/10.37891/kpej.v1i1.39

Jumaeroh, S., \& Zuhaida, A. (2019). Pengaruh Penggunaan Media Edmodo Dengan Model Pembelajaran Discovery Learning Terhadap Hasil Belajar Ipa Materi Tekanan Pada Zat. Thabiea: Journal of Natural Science Teaching, 2(2), 118-122. Doi: https://doi.org/10.21043/thabiea.v2i2.5995 [Indonesian]

Kartal, G. (2019). What's up with WhatsApp? A Critical Analysis of Mobile Instant Messaging Research in Language Learning. International Journal of Contemporary Educational Research, 6(2). https://doi.org/10.33200/ijcer.599138

Mamonto, M. R., Odja, A. H., \& Abdjul, T. (2021). The Effect of E-Learning Application through the Use of Whatsapp-Assisted Edmodo on the Students' Learning Outcomes in the Concept of Sound Waves. Jurnal Pendidikan Fisika, 9(1), 56-62. https://doi.org/10.26618/jpf.v9i1.4361

Rosmayanti, D. \& Hilva Y. 2018. The Relationship Between Students' Motivation Andtheir Learning Achievement. Proffesional Journal of English Education, 1 (6), 783-788. https://dx.doi.org/10.22460/project.v1i6.p783$\underline{788}$

Safdari, M. (2021). Contributions of edmodo social learning network to iranian efl learners' writing accuracy. Call-Ej, 22(1), 355-373.

Sakkir, G., Dollah, S., \& Ahmad, J. (2020). Favorite ELearning Media in Pandemic Covid-19 Era (Universitas Muhammadiyah Sidenreng Rappang). Jurnal Studi Guru Dan Pembelajaran, 3(3), 480-485. $\quad$ https://www.ejournal.my.id/jsgp/article/view/435
Sefriani, R., Sepriana, R., Wijaya, I., Radyuli, P., \& Menrisal. (2021). Blended learning with edmodo: The effectiveness of statistical learning during the covid-19 pandemic. International Journal of Evaluation and Research in Education, 10(1), 293299.

https://doi.org/10.11591/IJERE.V10I1.20826

Susilawati, S., \& Supriyatno, T. (2020). Online Learning Through WhatsApp Group in Improving Learning Motivation in the Era and Post Pandemic COVID -19. Jurnal Pendidikan, 5(6), 852859.

Vania, P. F., Setiawan, W., \& Wijaya, A. F. C. (2018). Edmodo as Web-Based Learning to Improve Student's Cognitive and Motivation in Learning Thermal Physics. Journal of Science Learning, 1(3), 110. https://doi.org/10.17509/jsl.v1i3.11796

Zhafira, N. H., Yenni E., \& Chairiyaton. (2020). Persepsi Mahasiswa Terhadap Perkuliahan Daring Sebagai Sarana Pembelajaran Selama Masa Karantina Covid-19. Jurnal Bisnis dan Kajian Strategi Manajemen, 4 (1), 37-45. doi: https://doi.org/10.35308/jbkan.v4i1.1981

[Indonesian] 